\title{
Lebetus scorpioides and Buenia jeffreysii (Teleostei: Gobiidae) found north of the Arctic Circle
}

\author{
Ingvar Byrkjedal', Rupert Wienerroither ${ }^{2}$ and Gjertrud Jensen ${ }^{2}$
}

Byrkjedal I, Wienerroither R and Jensen G. 2016. Lebetus scorpioides and Buenia jeffreysii (Teleostei: Gobiidae) found north of the Arctic Circle. Fauna norvegica 36: 47-50.

Two gobiid species, Lebetus scorpioides and Buenia jeffreysii, were recorded in northern Norway, for the first time north of the Arctic Circle. While both species were found on the continental shelf west of the Lofoten islands, one of them, L. scorpioides, was found north of $70^{\circ} \mathrm{N}$ off western Finnmark. The records represent a considerable northward extension of the distribution of these species. Being well within the size of reproductive individuals, the specimens appear to belong to resident populations most probably missed by earlier samplings.

doi: 10.5324/fn.v36i0.1952. Received: 2015-11-17. Accepted: 2016-04-28. Published online: 2016-05-20. ISSN: 1502-4873 (printed), 1891-5396 (electronic).

Keywords: Gobies; range; North Norway

1. Department of Natural History, University Museum of Bergen, University of Bergen, Allégt. 41, N-5020 Bergen, Norway

2. Institute of Marine Research, P.O. Box 1870 Nordnes, N-5817 Bergen, Norway

Corresponding author: Ingvar Byrkjedal

E-mail: ingvar.byrkjedal@uib.no

\section{INTRODUCTION}

The gobies (Gobiidae) are a speciose fish family distributed primarily in the tropics and subtropics, chiefly inhabiting marine and brackish waters (Nelson 2006). Most of the species live epibenthic in the littoral zone and are predators on small invertebrates. They spawn in spring and summer, depositing eggs in layers under shells, stones, etc. Eggs are guarded by the males and the young typically occur planktonic above the sea-bed (Miller 1986).

Of the 32 species of the Northeast Atlantic-Mediterranean fauna 11 are regularly found along the Atlantic coast of the Scandinavian Peninsula. While four of these species occur north of the Arctic Circle, the others are known only from the waters along the coast of southern Norway (Miller 1986, Pethon 2005). Two of these, Lebetus scorpioides (Collett, 1874) and Buenia jeffreysii (Günther, 1867), were recorded off northern Norway in the years 2008-2012. We here report these records and discuss the distribution of the two species in the northern waters.

\section{MATERIAL AND METHODS}

The fishes were obtained by the MAREANO, a project run by the Institute of Marine Research, Bergen, to map benthic organisms off the Norwegian coast (www.mareano.no), five of them as collected specimens and two recorded by video footage. The specimens were caught in a beam trawl (R/V 'G.O. Sars') with an opening of $2 \times 2 \mathrm{~m}$ and a mesh width of $4 \mathrm{~mm}$, towed on the bottom for $5 \mathrm{~min}$ at a speed of 1 knot. The material was identified to family level, sorted and fixed in formalin on board. The fishes were subsequently transferred to the University Museum of Bergen, and the final species identification was done at the museum as the material was transferred to $75 \%$ ethanol for permanent storage. The video footage was taken by the Institute of Marine Research's video platform Campod. This is a tripod equipped with low light CCD, high definition (HD) video cameras and lights. The HD camera has manual zoom and focus and is mounted on a pan-and-tilt device. For the present observations the Campod was used parked on the seabed for detail studies. 


\section{RESULTS}

Four specimens of $L$. scorpioides were caught at three stations on the continental shelf west of the Lofoten Islands in May 2012, and one was video-recorded in the same general area in 2008 (Table 1, Figure 1). Yet another was identified from a video recording made in 2010 as far north as Lopphavet, western Finnmark.

The captured specimens were identified to species from diagnostic characters including lack of anterior membrane of pelvic disc and fin ray counts of 10-11 in $\mathrm{D}_{2}$ and 8-9 in $\mathrm{A}$, while the video-recorded specimens were identified from dorsal fin colour patterns (as described by Miller 1986), relative height of the dorsal fins, and light-coloured caudal peduncle (Figure 2, Figure 3). The total length of the captured specimens varied from 32.3 to $34.5 \mathrm{~mm}$ (Table 1). Both males and females were represented among these specimens, as judged from dorsal fin pigmentation, but two of the specimens had somewhat damaged fins, and a less clear pigmentation pattern probably due to the preservation fluid, causing an uncertain sex identification. Both video-recorded specimens were males.

The fishes were recorded at depths from 169 to $225 \mathrm{~m}$ and bottom temperatures from 7.0 to $7.5{ }^{\circ} \mathrm{C}$. The bottom substrate consisted of sand (stations Rst 814-30, Rst 849-29), gravelly sand with coral rubble (station Rst 667-9; Tandberg et al. 2012). At the video stations, sand/gravelly sand was noted at Rst 286 (BuhlMortensen and Buhl-Mortensen 2009) and bedrock/gravelly sand/depression with muddy sand at Rst 368 (Jørgensen et al. 2012).

One specimen of B. jeffreysii was caught off Lofoten in 2012 at $146 \mathrm{~m}$ depth and a temperature of $7.4{ }^{\circ} \mathrm{C}$. Among diagnostic characters observed were 27 scales along the lateral line; 6 rays in $\mathrm{D}_{1}$, the second ray elongated, suborbital papillae row $\mathrm{b}$ (Miller 1986) short and situated behind rear border of eye, and no transverse ramifications found between rows $b$ and $c$. The total length of this specimen was $48.2 \mathrm{~mm}$. The specimen was identified as male from the elongated second ray in $\mathrm{D}_{1}$. At this station the bottom consisted of sand (station Rst 809-28; Tandberg et al. 2012).

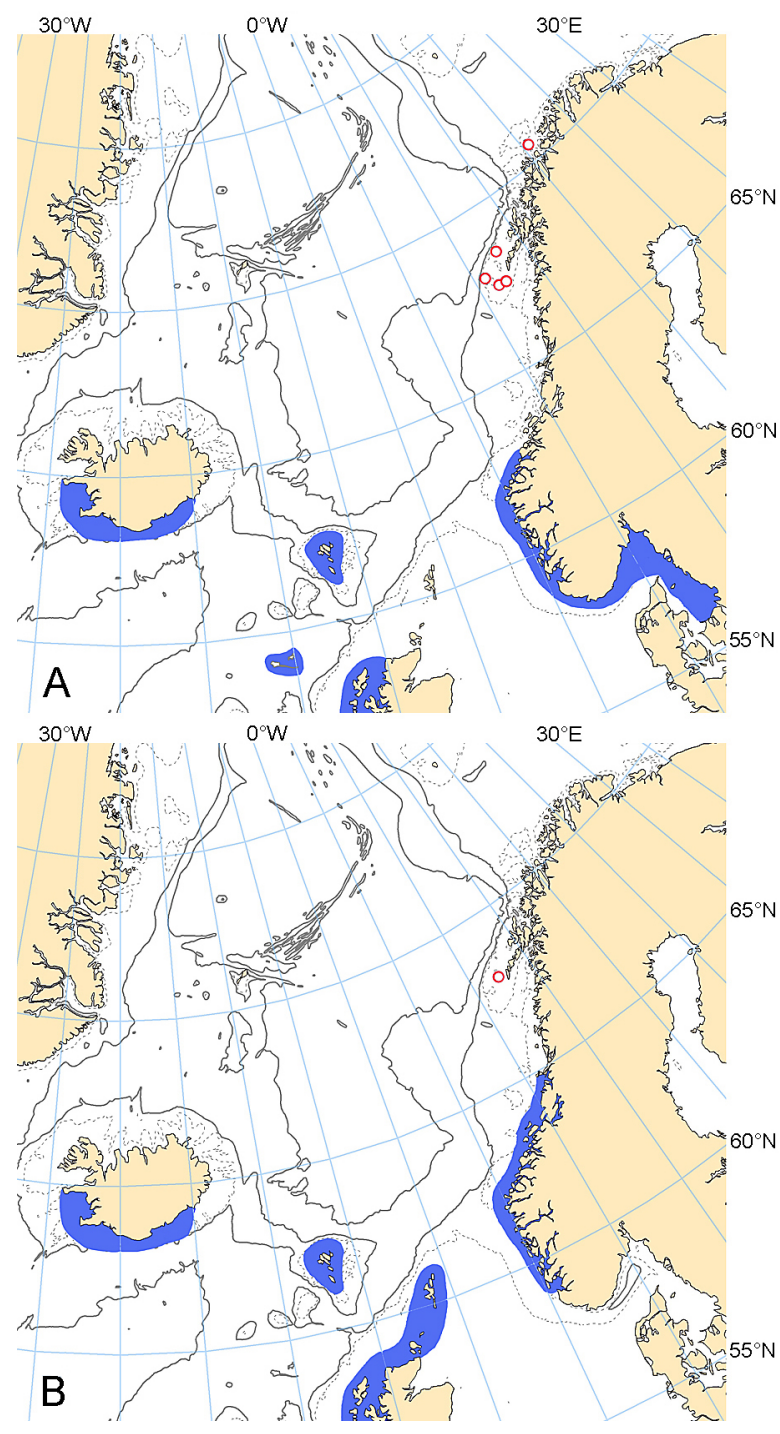

Figure I. Northernmost part of the ranges of Lebetus scorpioides (A) and Buenia jeffreysii (B). The new records are indicated by circles; previously known ranges according to Miller (1986), Pethon (2005) and Jónsson \& Pálsson (2013).

Table I. Data on the specimens of Lebetus scorpioides and Buenia jeffreysii recorded off northern Norway.

\begin{tabular}{lllllllll}
\hline Species & $\begin{array}{l}\text { Number of } \\
\text { specimens }\end{array}$ & Station & Coordinates & $\begin{array}{l}\text { Date } \\
\text { (dd.mm.yyyy) }\end{array}$ & $\begin{array}{l}\text { Depth } \\
(\mathrm{m})\end{array}$ & $\begin{array}{l}\text { Bottom } \\
\text { tempera- } \\
\text { ture }\left({ }^{\circ} \mathrm{C}\right)\end{array}$ & $\begin{array}{l}\text { Total } \\
\text { length } \\
(\mathrm{mm})\end{array}$ & $\begin{array}{l}\text { ZMUB } \\
\text { catalogue } \\
\text { numbers }\end{array}$ \\
\hline $\begin{array}{l}\text { Lebetus scorpi- } \\
\text { oides }\end{array}$ & $1 \mathrm{M}^{1}$ & Rst 638 & $70^{\circ} 34^{\prime} \mathrm{N}-20^{\circ} 10^{\prime} \mathrm{E}$ & 23.09 .2010 & 169 & $7.0^{2}$ & & \\
& $1 \mathrm{M}^{3}$ & Rst 286 & $68^{\circ} 23^{\prime} \mathrm{N}-3^{\circ} 01^{\prime} \mathrm{E}$ & 10.10 .2008 & 176 & & & \\
& $1 \mathrm{~F} ?$ & Rst $667-9$ & $6^{\circ} 32^{\prime} \mathrm{N}-9^{\circ} 37^{\prime} \mathrm{E}$ & 04.05 .2012 & 242 & 7.3 & 32.3 & 23019 \\
& $1 \mathrm{M} ?$ & Rst $814-30$ & $6^{\circ} 24^{\prime} \mathrm{N}-10^{\circ} 11^{\prime} \mathrm{E}$ & 11.05 .2012 & 225 & 7.5 & 34.2 & 23020 \\
& $1 \mathrm{M} ; 1 \mathrm{~F}$ & Rst $849-29$ & $6^{\circ} 24^{\prime} \mathrm{N}-10^{\circ} 50^{\prime} \mathrm{E}$ & 11.05 .2012 & 178 & 7.5 & $33.4 ; 33.5$ & 23021 \\
Buenia jeffreysii & $1 \mathrm{M}$ & Rst $809-28$ & $67^{\circ} 30^{\prime} \mathrm{N}-11^{\circ} 13^{\prime} \mathrm{E}$ & 11.05 .2012 & 146 & 7.4 & 48.2 & 23022 \\
\hline
\end{tabular}

1. Specimen recorded on video footage, still-picture in Figure 2; 2. From a station 3'N and 3'E away; 3. Specimen recorded on video footage, still-picture in Figure 3. 

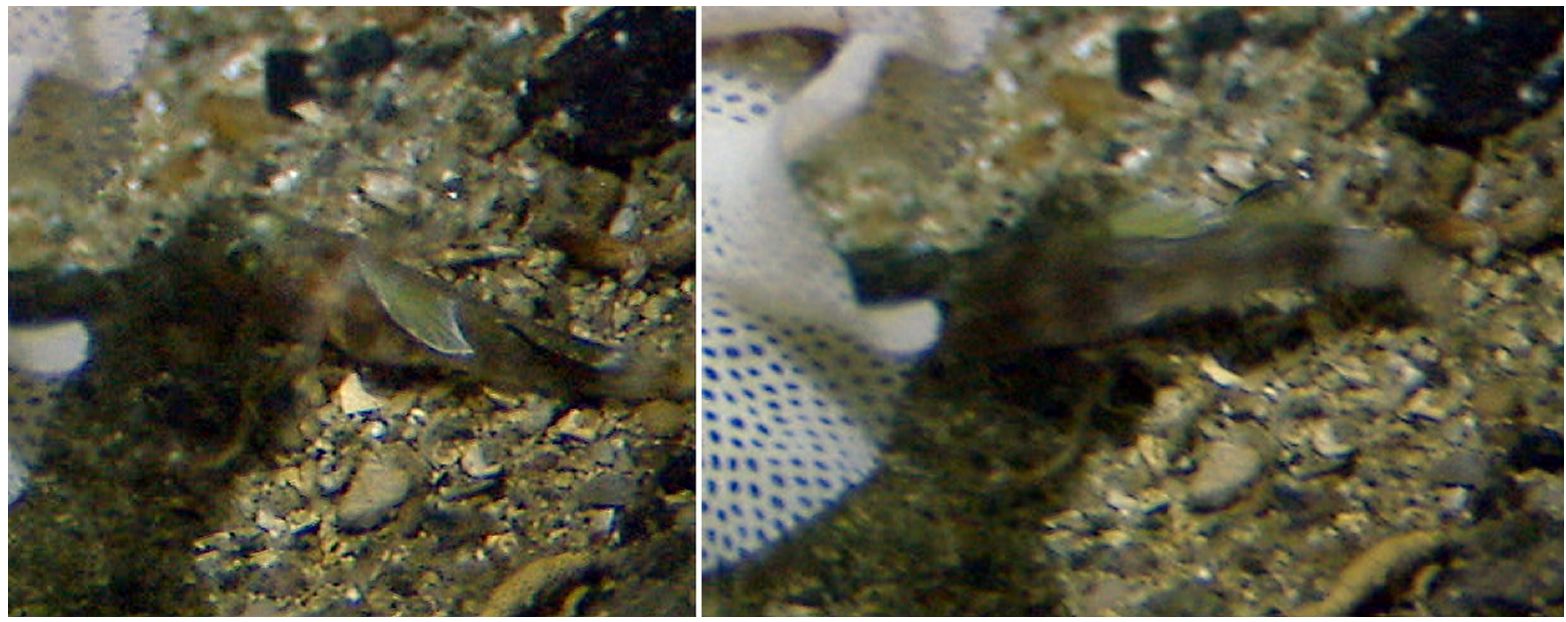

Figure 2. Male Lebetus scorpioides recorded on video footage at MAREANO station Rst 638. The fish was filmed while dashing from right to left, to take cover under a Reteporella sp. (Bryozoa). The characteristic first dorsal fin is clearly visible on the left image and the pale-coloured caudal peduncle on the right.

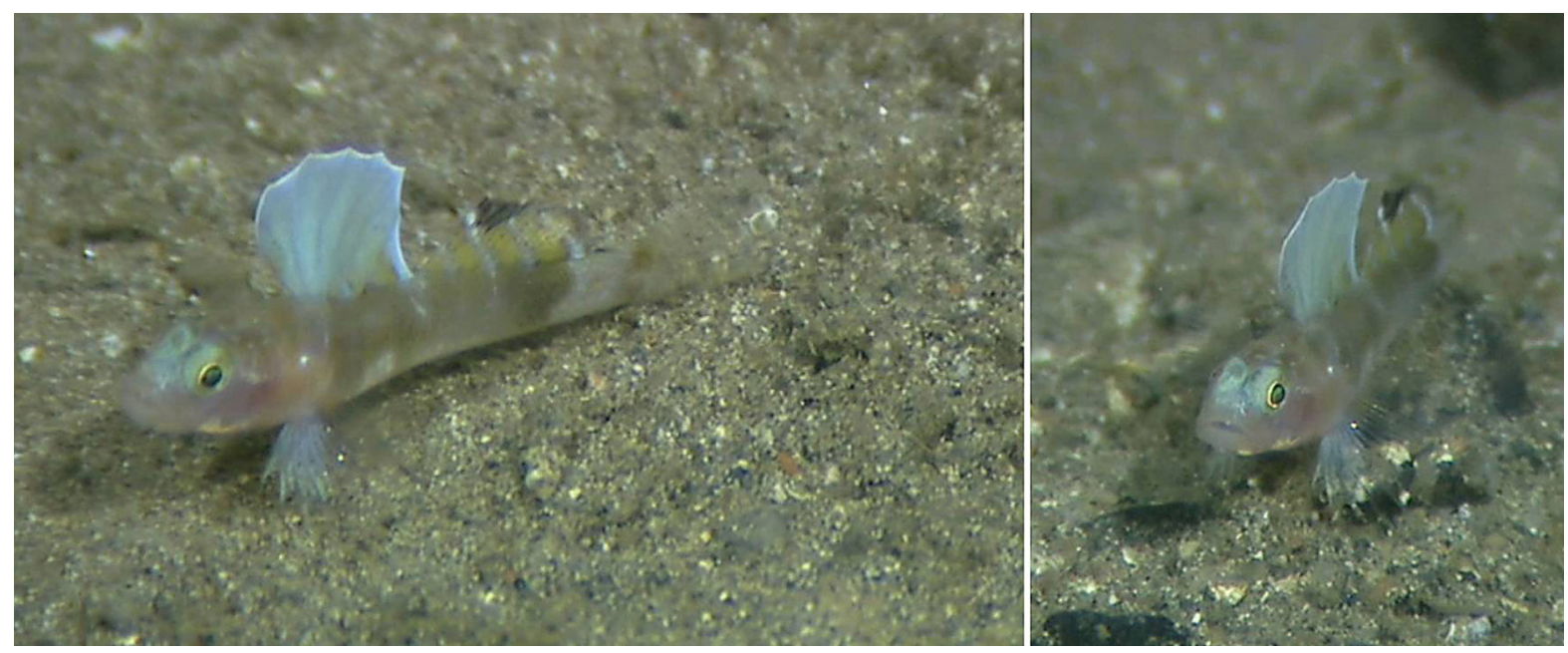

Figure 3. Male Lebetus scorpioides recorded on video footage at MAREANO station Rst 286.

\section{DISCUSSION}

These records extend the range of $L$. scorpioides approximately $1000 \mathrm{~km}(1850 \mathrm{NM})$, and that of $B$. jeffreysii about $300 \mathrm{~km}(550$ NM) north of their known Norwegian distribution (Miller 1986, Pethon 2005), and for the first time the two species are found north of the Arctic Circle. The records were in the deeper part of the depth range for both species (e.g. Pethon 2005) but still on the continental shelf and in predominantly coastal waters with a fairly high temperature (Blindheim 2004).

Fisheries cruises are routinely carried out in Norwegian waters, but for bottom fish sampling almost exclusively shrimp trawls of type Campelen 1800 are used, with a mesh width of $80 \mathrm{~mm}$ in the front and $16-18 \mathrm{~mm}$ in the codend (e.g. Michalsen et al. 2013). This gear may easily be too coarse to sample fishes as small as these, and generally they are often missed in fish surveys for such reason (Ellis and Rogers 2015); moreover, small Gobiidae are not commercially interesting fishes targeted by fisheries cruises. Also Pethon (2005) pointed out that the small size of $L$. scorpioides might make it less often caught, and he assumed the species could be more common in Norwegian waters than previously thought. Both species may be characterized partly as cryptobenthic (Zander 2011, Baldock and Kay 2012), living in cavities and other dark places (L. scorpioides), or lying buried in sandy bottom substrate $(B$. jeffreysii). This would add to the difficulties of discovering these species, whether by camera recording technique like the one used by the MAREANO project, or by sampling with more traditional fishing gear.

The oceanographic conditions along the coast of northern Norway are characterized by a flow of warm coastal and Atlantic water continuing into the southern part of the Barents 
Sea (Blindheim 2004, Ozhigin et al. 2011). Conditions suitable for the two goby species may have existed for long, and considering the previous use of less suitable gear for such small non-targeted fish species, we find it most probable that the records represent previously unknown populations, rather than recent colonizations. It is reasonable to assume that both species are distributed along the coast of Norway north to the present localities, and at least the northernmost of the two species, $L$. scorpioides, might even be expected to occur along much of the coast of Finnmark.

Apart from the pelagic Crystallogobius linearis (Düben, 1845) three bottom-living species of Gobiidae are found northwards along the coast of northern Norway, beyond the Arctic Circle. These are Gobiusculus flavescens (Fabricius, 1779), Pomatoschistus minutus (Pallas, 1770), and Pomatoschistus norvegicus (Collett, 1902). Only the latter is known to occur at similar depths as L. scorpioides and $B$. jeffreysii (Miller 1986, Pethon 2005), and earlier confusion with this species cannot be ruled out (cf. Baldock and Kay 2012). The specimens reported by us were within the size of reproductively mature individuals, and this might indicate that they belonged to a resident population in these waters.

\section{ACKNOWLEDGEMENTS}

We would like to thank the personnel of the MAREANO project, IMR, Norwegian seafloor mapping programme, www.mareano.no, and Katrine Kongshavn at the University Museum of Bergen, for securing the specimens for the museum collections. We are also grateful to two anonymous reviewers for their comments on the manuscript.

\section{REFERENCES}

Baldock L, Kay P. 2012. New records of some rare British and Irish gobies (Teleostei: Gobiidae). Marine Biodiversity Records 5: e25. doi: 10.1017/S175526721200005X

Blindheim J. 2004. Oceanography and climate. In: Skjoldal HR (ed). The Norwegian Sea ecosystem. Tapir Academic Press. pp. 65-96.

Buhl-Mortensen L, Buhl-Mortensen P. 2009. MAREANOTOKT 2008104 og 2008114, samlet toktrapport fra bunnkartlegging i Troms II og Nordland VII 2008. Toktrapport/ Havforskningsinstituttet/ISSN 1503-6294/Nr. 4 - 2009, 55 p.

Ellis J, Rogers S. 2015. Gobies (Gobiidae). In: Heessen HJL, Daan $\mathrm{N}$ and Ellis JR (eds). Fish atlas of the Celtic Sea, North Sea, and Baltic Sea. Wageningen Academic Publishers. pp. 396-411.

Jónsson G, Pálsson J. 2013. Íslenskir fiskar. Mál og menning. Jørgensen LL, Buhl-Mortensen P, Holte B. 2012. MAREANOTOKT 2010, samlet toktrapport fra bunnkartlegging på Nordkapptransektet, Troms III and Nordland VI. Toktrapport/ Havforskningsinstituttet/ISSN 1503-6294/Nr. 2-2012, 53 p.

Michalsen K, Dalpadado P, Eriksen E, Gjøsæter H, Ingvaldsen
RB, Johannesen E, Jørgensen LL, Knutsen T, Prozorkevich D, Skern-Mauritzen M. 2013. Marine living resources of the Barents Sea - ecosystem understanding and monitoring in a climate change perspective. Marine Biology Research 9: 932-947. doi:10.1080/17451000.2013.775459

Miller PJ. 1986. Gobiidae. In Whitehead PJP, Bauchot M-L, Hureau J-C, Nielsen J and Tortonese E (eds). Fishes of the North-eastern Atlantic and the Mediterranean. UNESCO. pp. 1019-1085.

Nelson JS. 2006. Fishes of the world. John Wiley \& Sons.

Ozhigin VK, Ingvaldsen RB, Loeng H, Boitsov VD, Karsakov AL. 2011. Introduction to the Barents Sea. In: Jakobsen T and Ozhigin VK (eds). The Barents Sea: ecosystem, resources, management. Tapir Academic Press. pp. 39-76.

Pethon P. 2005. Aschehougs store fiskebok. Aschehoug.

Tandberg AH, Holte B, Buhl-Mortensen P. 2012. MAREANO toktrapport 2012. Toktrapport/Havforskningsinstituttet/ISSN 1503-6294/Nr. 8 - 2012, 38 p.

Zander CD. 2011. Morphological adaptations to special environments of gobies. In: Patzner RA, Van Tassell JL, Kovačić M, Kapoor BG (eds). The biology of gobies. Science Publishers. pp. 345-366.

Editorial responsibility: Jan Davidsen.

This article is open-access and distributed under the terms of the Creative Commons Attribution 4.0 International license. This permits all non-commercial use, distribution, and reproduction in any medium, provided the original work is properly cited.

(http://creativecommons.org/licenses/by/4.0/). 